\title{
KONTEKSTUALISASI FILSAFAT POLITIK AL-FÂRÂBÎ DALAM PEMIKIRAN POLITIK MODERN
}

\author{
Moh. Asy'ari Muthhar \\ Institut Ilmu Keislaman Annuqayah Guluk-guluk Sumenep, Indonesia \\ E-mail: ari2504na1@yahoo.com
}

\begin{abstract}
The article describes that in light of al-Madinah alFâdilah, al-Fârâbî idealized the relationship between state and its citizens based on ethical values. This is in order to create a society who recognize the truth and enforce it in the form of cooperation with the state to build mutual prosperity. According to al-Fârâbî, society is a pivotal element of the creation of state. Within nationstate realm, the members of society must positively demonstrate their contribution based on their respective capability. Al-Fârâbî called, in addition, for the existence of freedom (al-burriyah) for all people. The task of a state leader is to provide his members guidance to justly stride on right path in accordance with religious doctrines and to prevent them from going astray from the initial objective of state creation, i.e. triumphing happiness within the world and the hereafter. Al-Fârâbî's political thought has great influence in the next development of the modern democracy. The article indicates that al-Fârâbî's concept of freedom has been subsequently reinterpreted by the next Muslim scholars emphasizing that the concept of freedom he deemed is not a borderless freedom.
\end{abstract}

Keywords: al-Madînah al-Fâdilah; democracy, civil society, good governance.

\section{Pendahuluan}

Membahas tentang politik modern tidak bisa dilepaskan dari demokrasi yang di dalamnya menyaratkan adanya civil society dan good governance. Karena konsep-konsep ini bersumber dari Barat menyebabkan adanya polemik di kalangan umat Islam akan kompatibilitasnya dengan Islam. Bagi mereka yang menganggap demokrasi tidak sesuai dengan 
ajaran Islam, seperti Abû al-A'lâ al-Mawdûdî (w. 1979 M), ia menawarkan pemikiran yang dikenal dengan teodemokrasi. Di sisi lain, ada kalangan yang menafsirkan shûrâ di dalam al-Qur'ân merupakan fondasi awal dari demokrasi itu sendiri. Perdebatan dua arus besar di internal umat Islam ini terus berlangsung sampai sekarang, dan diperkeruh lagi dengan silang pendapat tentang relasi agama (Islam) dan negara. ${ }^{1}$

Al-Fârâbî yang hidup pada abad ke-9 Masehi menawarkan tatanan kehidupan berbangsa dan bernegara dalam karya monumentalnya Kitâb Arâ' Abl al-Madînah al-Fâdilah. Di dalam karya-karyanya, al-Fârâbî, tidak pernah menyebut istilah demokrasi (al-dîmuqrâtîyah), tapi konsep alMadinah al-Fâdilah oleh banyak pemikir dipahami sebagai demokrasi. Tetapi, ada elemen-elemen penting di dalam syarat terciptanya al-Madinah al-Fâdilah yang sepertinya kurang sejalan dengan demokrasi, di mana alFârâbî menafikan kebebasan masyarakat. Padahal kebebasan ini merupakan syarat penting dalam terwujudnya tatanan masyarakat

1 Relasi agama dan negara ini setidaknya memunalkan tiga paradigma; pertama, paradigma intergralistik. Dalam perspektif ini agama dan negara menyatu (integrated). Pemerintahannya diselenggarakan atas "kedaulatan Tuhan", karena pendukung paradigma ini meyakini kedaulatan berasal dan berada di "tangan Tuhan". Lihat Imam Khumaini, al-Hukûmah al-Islâmîyah (Iran: al-Harakah al-Islâmiyah, 1389 H.), 35. Lihat juga Abû al-Ḥasan al-Mâwardî, al-Aḥkâm al-Sultânîyah (Beirut: Dâr al-Kitâb al-Alamiyah, t.th.), 5. Paradigma integralistik ini yang kemudian melahirkan paham negara-agama, di mana kehidupan kenegaraan diatur dengan menggunakan prinsip-prinsip keagamaan, sehingga melahirkan konsep Islam din wa al-dawlah. Lihat James P. Piscatory, Islam in a World Nation-State (New York: Cambridge University Press, 1986), 9. Kelompok ini dikembangkan oleh tokoh Muslim populer di antaranya, Ḥasan al-Bannâ (1906-1949), Sayid Qutub (1906-1966), Abu al-A'la Al-Maududi, dan lain-lain. Kedua, paradigma simbiotik. Paradigma ini mengasumsikan bahwa agama dan negara berhubungan secara simbiotik, yaitu suatu hubungan yang bersifat timbal balik dan saling membutuhkan. Dalam konteks ini, agama memerlukan negara, karena dengan negara agama dapat berkembang. Negara juga memerlukan agama untuk dapat berkembang dalam bimbingan etika dan moral-spiritual. Pemikiran ini dikembangkan oleh tiga tokoh terkenal yaitu Muḥmmad 'Abduh (1849-1905), Muhammad Iqbal (1873-1938), Ibn Khaldûn (1332-1406). Ketiga, paragdigma sekularistik. Paradigma ini mengajukan disparitas agama atas negara dan pemisahan negara atas agama. Konsep al-Dunyâ-alÂkhirat, al-Dîn-al-Dawlah, Umûr al-Dunyâ-Umûr al-Âkhirah didikotomikan secara diametral. Tokoh paradigma sekularistik ini di antaranya Ṭâha Husayn (1889-1973) dan 'Alî 'Abd al-Râziq (1888-1966) yang menyatakan bahwa Islam hanya sebuah agama dan tidak ada kaitannya dengan urusan negara. Lihat Ali Masykur Musa, Membumikan Islam Nusantara (Jakarta: Serambi, 2014), 151. 
demokratis. Di sinilah signifikansi dari kertas kerja ini yang ingin menelusuri bagaimana relevansi filsafat politik al-Fârâbî tersebut dengan pemikiran politik modern.

Manusia, menurut al-Fârâbî, adalah makhluk sosial yang tidak mungkin hidup sendiri-sendiri. Manusia hidup bermasyarakat dan saling membantu untuk kepentingan bersama dalam mencapai tujuan hidup, yakni kebahagiaan. ${ }^{2}$ Sifat dasar inilah yang mendorong manusia hidup bermasyarakat dan bernegara. Masyarakat terbaik adalah masyarakat yang bekerja sama, saling membantu untuk mencapai kebahagiaan, yang kemudian ia istilahkan dengan al-Madînah al-Fâdilah. ${ }^{3}$

John Locke (1632-1704 M) dan Jean-Jacques Rousseau (1712-1778 M) memandang rakyat sebagai penguasa, meskipun keduanya berbeda pendapat mengenai fungsi perjanjian. Kekuasaan yang dimiliki oleh setiap anggota masyarakat berdasarkan hukum alam. Setiap orang bertindak secara alamiah. Mereka mempunyai hak-hak persamaan dan kebebasan sebagai pemberian alam. Untuk memelihara dan melindungi hak-hak mereka itulah, mereka membentuk negara dan melengkapinya dengan menyerahkan sebagian atau semua kekuasan yang mereka miliki. ${ }^{4}$

Kemudian pada tahun 1792, muncul pula pendapat Thomas Paine (1737-1803). ${ }^{5}$ Dalam paradigmanya, masyarakat memiliki posisi berseberangan secara diametral dengan negara. Bahkan, dianggapnya sebagai antitesis negara. Dalam konteks ini, dibutuhkan apa yang disebut civil society. Dengan demikian, peran negara dalam menjalankan roda pemerintahan harus dibatasi sampai sekecil-kecilnya. Jadi, civil society menurut Paine ini adalah ruang di mana warga dapat mengembangkan kepribadian dan memberi peluang bagi pemuasan kepentingannya secara

2 Abû Naṣr al-Fârâbî, Kitâb Ârâ' Abl al-Madînah al-Fâdilah (Beirut: Dâr al-Mashriq, 1996), 118. Lihat juga Abû Naṣr al-Fârâbî, Kitâb al-Millah wa Nuṣ̂ṣ Ukhrâ (Beirut: Dâr al-Mashriq, 1986), 53. Frans Magniz-Suseno memberikan penjelasan bahwa tujuan dibentuknya negara adalah untuk menyejahterakan seluruh warga negara, bukan individu-individu tertentu. Dengan kesejahteraan semua masyarakat, maka kesejahteraan individu tercapai dengan sendirinya. Frans Magniz-Suseno, Etika Politik (Jakarta: Gramedia, 1994), 188.

3 al-Fârâbî, Kitâb Arâ' Abl al-Madinah al-Fâdilah, 117. Lihat juga Abû Naṣr al-Fârâbî, Kitâb al-Siyâasah al-Madanîyah (Beirut: Dâr al-Mashriq, 1993), 69.

${ }^{4}$ Jean-Jacques Rousseau, Kontrak Sosial, terj. Sumardjo (Jakarta: Erlangga, 1986), 14-15.

5 Philip S. Foner (ed.), The Complete Writings of Thomas Paine: With a Biographical Essay, and Notes, and Introductions Presenting the Historical Background of Paine's Writings (New York: The Citadel Press, 1945), 136. 
bebas tanpa paksaan. Paine mengidealkan terciptanya suatu ruang gerak yang menjadi domain masyarakat, di mana intervensi negara di dalamnya merupakan aktivitas yang tidak sah dan tidak dibenarkan. Oleh karenanya, civil society harus lebih kuat dan mampu mengontrol negara demi kebutuhannya. ${ }^{6}$ Konsekuensinya, negara bukan lagi menjadi rekan malah lawan secara diametral vis a vis dengan masyarakat.

Dalam paradigma politik Hegel, civil society berbeda dengan negara. Konsep yang disebut pertama, merupakan suatu wilayah, ruang, atau perantara di antara keluarga dan negara. Menurutnya, civil society terbentuk dari upaya kaum kapital borjuis yang banyak tercipta di Eropa abad ke-17 M. yang berupaya melepaskan diri dari tradisi kungkungan kekuasaan negara maupun keluarga feodal. Pengejawantahan dari upaya tersebut menciptakan tatanan sosial baru yang dicirikan oleh berbagai persaingan di sektor ekonomi. Kompetisi ekonomi ini terlihat dalam bentuk kerja, produksi, pertukaran jasa dan barang, serta perolehan harta. Ranah sosial yang independen dari negara demikian inilah yang oleh Hegel disebut civil society. Hegel lebih lanjut menjelaskan bahwa karena eksistensi civil society terbentuk dari arena persaingan ekonomi, yang inhern di dalam dirinya mengandung potensi perpecahan, mau tak mau ia butuh campur tangan negara. ${ }^{7}$

Karl Marx (1818-1883) melanjutkan dialektika pemikiran Hegel tentang civil society dalam mengembangkan teorinya tentang masyarakat borjuasi kapitalis. Senada dengan ekonom Adam Smith, Marx mengidentifikasi civil society berhubungan dengan dimensi ekonomi, terutama pasar. ${ }^{8}$ Sebagaimana pandangan filsafatnya, dia juga melihat civil society dari perspektif determinisme ekonomi bahwa yang menjadi basis kehidupan sosial dan politik manusia pada umumnya adalah modus produksi kehidupan material. Civil society sebagai tempat para anggotanya dengan bebas dapat mengejar keuntungan ekonomi, dikritik oleh Marx sebagai suatu "kamuflase" dari monopoli sarana produksi oleh kaum

${ }^{6}$ Gregory Claeys, Thomas Paine, Social and Political Thought (Wellington: Unwin Himan, t.th.), $1-2$.

7 Dawam Rahardjo, Masyarakat Madani: Agama, Kelas Menengah, dan Perubahan Sosial (Jakarta: LP3ES, 1999), 67. Baca juga Franz Magnis-Suseno, Pemikiran Karl Marx: dari Sosialisme Utopis ke Perselisihan Revisionisme (Jakarta: Gramedia Pustaka Utama, 2005), 77 78.

8 Chris Hann, "Political Society and Civil Anthropology", dalam Chris Hann dan Elizabeth Dunn, Civil Society: Challenging Western Models (New York: Routledge, 1996), 4. 
borjuis yang mengeksploitasi kaum proletar. Dengan demikian, civil society bagi Marx hanyalah merupakan fase transisi yang masih tetap mengandung kontradiksi-kontrradiksi hubungan ekonomi masyarakat kapitalis, yang pada akhirnya pasti akan hancur dari dalam, karena terjadi transformasi total menuju masyarakat sosialis. ${ }^{9}$

Kalangan pemikir Muslim abad pertengahan juga mencetuskan teori dalam konteks kekhalifahan. Al-Mâwardî (w. 450 H./1058 M), misalnya, yang menekankan teorinya pada pentingnya kepemimpinan umat (imâmab), posisi khalifah sebagai imam, serta kewajiban dan fungsi imam. Sentralitas imam dalam pemerintahan menjadi perhatian utama, bukan pada bagaimana proses pembentukan negara berlangsung dan bagaimana peran atau sumbangan Islam dalam proses tersebut. Dengan kata lain, dalam mempertautkan Islam dengan pembentukan negara, pendekatan yang digunakan al-Mâwardî lebih bersifat normatif-doktriner, terlalu fokus pada persoalan personalitas pemimpin, serta tidak memperhatikan pendekatan sosiologis. ${ }^{10}$ Akibatnya, bagaimana peran masyarakat dalam kehidupan bernegara lepas dari pandangannya.

Misalnya pendapat al-Mâwardî mengenai bentuk negara, kendatipun pemimpin negara dipilih tetapi dia tetap memilih negara sistem monarki yaitu sistem kerajaan yang sedang berkembang di masanya. Al-Mâwardî juga memberi syarat calon pemimpin negara harus berbangsa Arab dan bersuku Quraisy. ${ }^{11}$ Ibn Khaldûn (w. 809 H./1406 M) yang hidup lama setelah al-Mâwardî juga masih menyaratkan seorang pemimpin negara Islam harus bersuku Quraisy. ${ }^{12}$ Syarat yang dikemukakan oleh kedua pakar negara Islam ini untuk sekarang tentu tidak realistis. Demikian juga dengan bentuk pemerintahan monarki, nampaknya sudah mulai muncul kritik seperti tidak berdasarkan Islam.

Hal yang senada juga bisa dilihat dalam pandangan Abû al-A'lâ alMawdûdî, di mana ia menegasikan demokrasi secara prinsipil, bahkan menganggapnya sama dengan syirik. Baginya, dalam demokrasi rakyat dapat menetapkan hukum sendiri dan karenanya dapat pula melaksanakan semua aspirasi yang mereka miliki, padahal sebenarnya

\footnotetext{
9 Antony Giddens, Capitalism and Modern Social Theory: an Analysis of Writings of Marx, Durkheim, and Max Weber (London: Cambridge University Press, 1971), 55.

10 Qamaruddin Khan, Kekuasaan, Pengkhianatan dan Otoritaas Agama: Telaah Kritis Teori alMawardi tentang Negara (Yogyakarta: Tiara Wacana, 2000), 39-87.

11 al-Mâwardî, al-Ạ̣kâm al-Sultânîyah, 6.

12 Ibn Khaldûn, Muqaddimah (Beirut: Dâr al-Fikr, t.th.), 193-196.
} 
masyarakat Muslim tidak dapat berbuat seperti itu. Kebebasan mereka dibatasi oleh Allah. ${ }^{13}$ Makanya, ia kemudian menawarkan konsep teodemokrasi sebagai solusi dari kekurangan dalam demokrasi. Al-Mawdûdî dalam konteks ini sepertinya sepakat dengan demokrasi, tetapi ia ingin menghindar dari tindakan-tindakan yang menyeret pada kehidupan sekuler. Itu sebabnya ia menginginkan penerapan demokrasi dengan kedaulatan Tuhan.

Fazlur Rahman menolak konsep kedaulatan Tuhan seperti yang dikemukakan al-Mawdûdî. Menurut Rahman, apabila kita mengakui pendapat seperti itu, berarti kita mengakui bahwa Allah itu berdaulat secara politik. ${ }^{14}$ Rahman juga tidak setuju dengan syarat kepala negara harus suku Quraisy yang diberikan oleh pakar Islam klasik, kendatipun pendapat itu berasal dari hadîth nabi yang diucapkan kembali oleh Abû Bakar ketika pertemuan di Balai Sa ${ }^{6} \hat{i} d a h .{ }^{15}$ Barangkali Rahman melihat hadîth itu tidak mempunyai konteks dengan zaman sekarang. Rahman lebih memilih sistem pemerintahan demokrasi, karena kepala negara harus dipilih secara bebas oleh rakyat. ${ }^{16}$

Perdebatan ini terus berlanjut sampai sekarang, masing-masing model dan bentuk negara tersebut memiliki kelemahan dan kelebihan, tinggal bagaimana masyarakat dalam sebuah kawasan memilih di antara beragam bentuk tersebut sesuai dengan kondisi masyarakatnya. Yang terpenting adalah tetap pada koridor tujuan awal terbentuknya sebuah negara. Idealnya, ada empat fungsi yang semestinya direalisir sesuai dengan tujuan terciptanya negara, yaitu melaksanakan ketertiban, mengusahakan kesejahteraan dan kemakmuran rakyat, pertahanan, dan menegakkan keadilan. ${ }^{17}$ Ketika tujuan-tujuan ini tercapai, maka disitulah wujud alMadînah al-Fâdilah dalam konsep negara al-Fârâbî, di mana ia mendambakan sebuah kota yang penuh dengan kedamaian, egaliter, makmur, dan kehidupan masyarakatnya tenang.

13 Abû A'la al-Mawdûdî, The Political Theory of Islam (Pathankot: Makta-e Jama'at Islami, t.th.), 29-30.

14 Fazlur Rahman, "Implementation of the Concept of State in the Pakistani Milieu", Islamic Studies, No. 6 (September 1967), 208.

15 Khalid Ibrahim Jindan, Teori Politik Islam: Telaab Kritis Ibnu Taimiyah tentang Pemerintahan Islam, terj. Masrohin (Surabaya: Risalah Gusti, 1995), 2.

${ }^{16}$ Rahman, "Implementation of the Concept of State, 205.

${ }^{17}$ Moh. Mufid, Politik dalam Perspektif Islam (Jakarta: UIN Jakarta Press, 2004), 24. 
Membahas tentang pemikiran al-Fârâbî mengenai al-Madînah alFâdilah banyak kalangan yang melihat gagasannya ini dipengaruhi oleh pemikiran Plato dan Aristoteles. Makanya, ia kemudian disebut sebagai guru kedua (al-mu'allim al-thâni) sebagai kelanjutan dari Aristoteles yang disebut guru pertama (al-mu' allim al-awal). ${ }^{18}$ Pemikiran tentang al-Madinah al-Fâdilah ini kemudian diterjemahkan dengan beragam istilah oleh beberapa kalangan, seperti civil society dan masyarakat madani. ${ }^{19}$ Gagasannya tentang al-Madînah al-Fâdilah tersebut, al-Fârâbî sebenarnya bertumpu pada dua hal; pertama, konsep tentang pemimpin dan yang dipimpin, atau konsep kepemimpinan. Kedua, konsep kebahagiaan. Ia menegaskan bahwa manusia hidup butuh seorang pemimpin (múallim) untuk menemukan kebahagiaan mereka. ${ }^{20}$

Konsep al-Madînah al-Fâdilah yang ditawarkan oleh al-Fârâbî ini akan dicoba untuk ditelaah sejauhmana ia memberikan kontribusi dalam khazanah pemikiran politik, terutama dalam perdebatan panjang persoalan bentuk masyarakat dan negara seperti dipaparkan di atas. Apakah al-Fârâbî lebih cenderung pada teokrasi, apakah monarki, atau justru ia memperkuat pandangan politik al-Mawdûdî dengan konsep teodemokrasi, sebab sudah maklum bersama bahwa al-Madînah al-Fâdilah selama ini diterjemahkan oleh beberapa kalangan sebagai masyarakat madani atau civil society. Tatanan masyarakat demikian adalah bagian

18 Atang Abdul Hakim, dkk., Filsafat Umum: dari Mitologi sampai Teofilosofi (Bandung: CV. Pustaka Setia, 2008), 447-449.

19 Masyarakat madani ini diperkenalkan pertama kali oleh Anwar Ibrahim pada tahun 1994. Ia mempunyai ciri yang khas, yaitu: kemajemukan budaya (multicultural), hubungan timbal balik (reprocity), dan sikap saling memahami dan menghargai. Dalam melaksanakan ide-ide yang mendasari masyarakat madani harus memperhatikan hal-hal penting seperti: prinsip moral, keadilan, kesamaan, musyawarah, dan demokrasi. Di Indonesia, konsep masyarakat madani digagas oleh Nurcholish Madjid. Istilah tersebut merujuk pada kondisi masyarakat Madinah dalam masa kepemimpinan Rasulullah. Dalam wacana akademis, perspektif Islam civil society diperkenalkan oleh Amien Rais pada Simposium Nasional Cendekiawan Muslim tahun 1990. Pada kesempatan itu Amien Rais memaparkan konsep civil society sebagai masyarakat yang mampu melahirkan berbagai organisasi, inisiatif, dan rangkaian aksi sosial dari bawah, bukan dari pemegang otoritas kekuasaan. Lihat Arskal Salim, "Between ICMI dan NU: The Contested Representation of Muslim Civil Society in Indonesia, 1990-2001", al-Jami'ab: Journal of Islamic Studies, Vol. 49, No. 2 (2011), 297. Lihat juga Amien Rais, Indonesian Civil Society 2006 (Jakarta: YAPPIKA, 2006), 18.

20 al-Fârâbî, al-Siyâsah al-Madanîyah, 86. 
inhern dalam kehidupan demokrasi, tetapi di sisi lain al-Fârâbî juga menolak adanya kebebasan bagi warga negara, ${ }^{21}$ padahal di antara syarat terbangunnya demokrasi adalah pemberian kebebasan kepada masyarakat. ${ }^{22}$

\section{Sketsa Biografis al-Fârâbî}

Nama lengkap al-Fârâbî adalah Abû Naṣr Muhammad ibn Muhammad ibn Tarkhan ibn Awzalagh al-Fârâbî. ${ }^{23}$ Dalam bahasa latin al-Fârâbî dikenal dengan nama al-Farabius atau Avennasar. ${ }^{24}$ Dalam karyanya yang berjudul Kitâb Ârâ' Abl al-Madînah al-Fâdilab disebutkan bahwa al-Fârâbî lahir pada tahun $259 \mathrm{H} / 870 \mathrm{M}^{25}$

Semua ilmuwan mengakui bahwa al-Fârâbî mampu memahami pemikiran dan filsafat Yunani. Terutama pemikiran Plato dan Aristoteles. Pemahaman dia tentang pemikiran dua tokoh Yunani tersebut dapat dilihat dalam karyanya yang berjudul Kitâb al-Jam' bayn Ra'yai alHâkîmayn. ${ }^{26}$ Karya ini berisi tentang komentar al-Fârâbî terhadap dua arus pemikiran filsafat Plato dan Aristoteles yang oleh banyak kalangan dianggap berbeda, tapi bagi al-Fârâbî justru keduanya tidak ada perbedaan. Sampai sekarang belum ada ilmuwan yang menolak bahwa alFârâbî memahami warisan pemikiran dua tokoh Yunani tersebut.

Selain memberi komentar terhadap pemikiran filsafat Yunani, alFârâbî juga mempunyai karya-karya orisinal baik tentang psikologi maupun metafisika. Karya-karya tersebut antara lain: al-'Aqlwa al-Ma'qûl,

21 Ibid., 95.

22 Beberapa kalangan menyebutkan adanya perbedaan antara kebebasan dengan kebebasan politik. Artinya, bisa saja suatu masyarakat bebas tanpa adanya kebebasan politik. Atau juga sistem demokrasi yang bercirikan partisipasi dan kehendak umum, tetapi menekan kebebasan individu. Lihat Masykuri Abdillah, Demokrasi di Persimpangan Makna (Yogyakarta: Tiara Wacana, 1999), 134.

23 al-Bier Nashri Nadir, "Nubdhah 'an Târikh Hayât al-Fârâbî", dalam al-Fârâbî, Kitâb al-Jam‘ bayn Ra'yai al-Ḥ̂akimayn (Beirut: Dâr al-Mashriq, 1968), 71.

24 Paul Edwards, The Encyclopedia of Philosophy (New York: Macmillan dan Free Press, 1972), 179.

25 al-Fârâbî, Kitâb Arâ' Abl al-Madînah al-Fậilah, 11-12.

26 Dalam kitab ini, al-Fârâbî juga menjelaskan tentang bagaimana proses masuknya keilmuan Yunani ke kawasan Arab. Termasuk di dalamnya adalah era penerjemahan karya-karya berbahasa Yunani dan Suryani ke bahasa Arab yang diterjemahkan di daerah Iskandariah, Baghdad, Jundisyapur, Harran, dan lain-lain. Lihat al-Fârâbî, Kitâb al-Jam', 46-50. 
al-Nafs, al-Qumwah al-Nafsiyah, al-Wâhid wa al-Wạ̣dah, al-Jawhar, al-Makân dan al-Miqyâs, dan lain sebagainya. ${ }^{27}$

Karya al-Fârâbî dalam bidang sosial dan politik, di antaranya Kitâb Ârâ' Abl al-Madînah al-Fâdilah, Kitâb al-Siyâsah al-Madanîyah, Ibṣâ' al-Ulûm, Kitab Tahṣîl al-Sa âdah, Kitâb al-Millah wa Nușuṣ Ukhrâ, Fâdilat al-Ulùm wa al-Ṣinâ'ah, Maqâlah fî Aghrad mâ ba'd al-Thabî'ah, Kitâb Tanbîh 'alâ Sabîl alSa'âdah, dan Kitâb al-Fusûs, Fuṣ̂ll Muntaza'ah. Khusus untuk bidang musik, al-Fârâbî menulis pemikirannya dalam Kitâb al-Mûsiqâ al-Kabîr.

Satu hal yang perlu digarisbawahi dari seluruh karya al-Fârâbî dalam banyak bidang tersebut, ia tidak bisa dilepaskan dari pemikirannya dalam bidang filsafat. Jadi, dalam membahas apapun tetap dalam perspektif filsafat.

Pengaruh filsafat Yunani, dalam hal ini Plato dan Aristoteles, terlihat jelas dalam pemikiran politik al-Farabi. Ini terlihat dalam pemikiran Plato tentang negara. Negara ideal, menurut Plato, menganut prinsip mementingkan kebajikan. Artinya, pengetahuan dan segala sesuatu yang dilakukan atas negara harus dimaksud untuk mencapai kebajikan. ${ }^{28}$ Oleh karena itu, pengetahuan dengan demikian menjadi keharusan dan syarat utama seorang pemimpin, sehingga pemimpin memiliki kemampuan membentuk negara yang baik bagi masyarakat. Hubungan timbal balik dan pembagian kerja sosial juga merupakan prinsip pokok kenegaraan. ${ }^{29}$

Plato menghendaki adanya kerja sama antara manusia untuk memenuhi kepentingan mereka. Kesatuan mereka ini kemudian disebut masyarakat dan masyarakat itu adalah negara. Baginya, antara sifat-sifat manusia ada persamaannya dengan sifat-sifat negara. ${ }^{30}$ Masyarakat adil

${ }^{27}$ E.J. Brill (ed.), First Encyclopedia of Islam, 54.

${ }^{28}$ Kabul Budiyono, Teori dan Filsafat Ilmu Politike (Bandung: Penerbit Alfabeta, 2012), 84.

29 Ibid., 85. Saat lahir, al-Fârâbî langsung dihadapkan pada realitas politik yang kacau. Mungkin ini yang kemudian memberikan pengaruh tersendiri pada pola pemikiran alFârâbî selanjutnya. Ia lahir pada masa pemerintahan al-Mu'tamid (256-257 H/870-892 M), di mana pada masa itu kondisi sosial politik dinasti 'Abbâsîyah kacau. Pemberontakan dari berbagai golongan terus terjadi di berbagai wilayah kekuasaan Abbasiyah, sehingga sulit bagi khalifah al-Mu'tamid untuk mengendalikan. Stabilitas politik tidak bisa dikendalikan. Pada waktu itu, timbul berbagai macam pertentangan bahkan pemberontakan terhadap kekuasaan 'Abbâsîyah dengan beragam kepentingan yang memotivasinya. Motif itu di antaranya, persoalan keagamaan, kesukuan, perebutan kekayaan dan lain-lain. Lihat Munawir Syadzali, Islam dan Tata Negara (Jakarta: UI Press, 1990), 50 .

30 Abu Daud Basroh, Ilmu Negara (Jakarta: Bumi Aksara, 2010), 21. 
adalah masyarakat yang harmonis dan baik. Dalam buku Republic, ia mengemukakan bahwa mereka yang mempunyai kekuatan nalar terbesar (filsuf) diberikan kekuasaan untuk memerintah. ${ }^{31}$

Plato menolak dengan tegas prinsip-prinsip demokratia atau pemerintahan oleh rakyat yang dipraktikkan di negara Athena waktu itu. Yang diajukan adalah pemimpin filsuf. Kebencian Plato kepada demokratia terkait dengan peristiwa peradilan terhadap Socrates, yaitu peradilan berdasarkan aturan rakyat banyak yang berujung pada penjatuhan hukuman mati. Menurut Plato, Socrates bukan penjahat dan perusak moral, melainkan orang berakhlak mulia yang terbijak, terjujur, dan terbaik yang pernah dikenalnya. ${ }^{32}$

Pemikiran Plato tersebut yang kemudian pada akhirnya sangat berpengaruh besar terhadap pemikiran al-Fârâbî, sehingga muncul karya tentang al-Madînah al-Fâdilab. ${ }^{33}$ Karya al-Fârâbî yang berjudul Kitâb Ârâ' Abl al-Madînah al-Fâdilah ditulis pada 331-332 H./941-942 M. di Damaskus, ${ }^{34}$ sekitar 7 tahun sebelum meninggal dunia.

Lebih kurang sepuluh tahun lamanya al-Fârâbî hidup mondar-mandir antara Aleppo dan Damaskus. Hubungan baik antara dua penguasa kota ini telah berubah menjadi sangat buruk sekali, sehingga Sayf al-Dawlah menyerbu kota Damaskus yang kemudian dapat dikuasainya. Dalam penyerbuan ini, al-Fârâbî diikutsertakan, tapi nasib malang menimpa dirinya karena tidak lama setelah kemenangan itu, ia meninggal dunia di Damaskus pada tahun $339 \mathrm{H} / 950$ M. dalam usia 80 tahun. $^{35}$

\section{Konsep Masyarakat dan Negara}

Dalam susunan ketatanegaraan ideal al-Fârâbî menggunakan teori organis. ${ }^{36}$ Negara, bagi al-Fârâbî, tak ubahnya bagaikan susunan tubuh

31 David E. Apter, Pengantar Analisa Politik, terj. Setiawan Abadi (Jakarta: LP3ES, 1987), 58.

32 Pudja Pramana, Ilmu Negara (Yogyakarta: Graha Ilmu, 2009), 40.

33 Budiyono, Teori dan Filsafat Ilmu Politik, 84.

34 al-Fârâbî, Kitâb al-Siyâsah al-Madanîyah, 16.

35 Ibid.

36 Sebagian dari ciri-ciri organisme adalah sifatnya yang cepat berubah, supel dan elastis. Badan organisme yang hidup dapat menerima dan mengambil bahan-bahan dan zat-zat dari luar dirinya, lalu diolah dan dimasaknya untuk kebutuhan dirinya, dan dipisahkannya yang dianggap tidak perlu atau sudah mati. Juga di dalam badan organisme di dapati pula struktur dan hirarki, sehingga tiap-tiap bagiannya mempunyai kedudukan tertentu. Selain itu, paham organisme menetapkan bahwa bukan saja 
manusia yang sehat dan sempurna. Masing-masing anggotanya bekerja sama untuk menyempurnakan dan memelihara segala kebutuhan hidup bersama. Setiap anggota tubuh memiliki fungsi dan kemampuan berbedabeda yang masing-masing bertugas sesuai dengan kemampuan dan kesanggupannya. Di atas semua itu ada suatu anggota yang berfungsi sebagai kepala yang mengendalikan segala gerak dari keseluruhan bagian tubuh yang lain yaitu jantung. Demikian pula dengan negara, masingmasing rakyatnya mempunyai tugas dan kecakapan yang berbeda-beda, dipimpin oleh seorang kepala negara, sedang yang lainnya membantu dalam berbagai kedudukan. ${ }^{37}$ Pandangan al-Fârâbî ini bisa dikatakan sebagai representasi dari agama Islam yang telah menganalogikan negara sebagai tubuh manusia sebagaimana sering disebutkan dalam hạatithhadîth Rasulullah. ${ }^{38}$

Terlihat al-Fârâbî dalam filsafatnya lebih menekankan pemberdayaan manusia dalam satu negara sesuai dengan spesialisasi dan kemampuan masing-masing individu. Warga negara harus rela berkorban untuk kepentingan bersama dan juga untuk kepentingan negara. Dengan kata lain, saling membantu dan bekerja sama bukan hanya antar-warga negara, tetapi juga antara negara dan warganya. Dilihat dari sisi ini berarti alFârâbî menepiskan bentuk negara kapitalisme dan sosialisme komunis. ${ }^{39}$

Filsafat politik al-Fârâbî sesungguhnya banyak diilhami oleh teori politik Plato dan Aristoteles. ${ }^{40}$ Plato- dengan bertitik tolak dari manusia yang harmonis serta adil-menggunakan jiwa manusia atas tiga fungsi, yaitu keinginan, energi dan rasio. Jika keinginan serta energi, di bawah

keseluruhan menetapkan bagian-bagiannya, tetapi bagian-bagian itu menetapkan pula keseluruhannya. Paham ini pernah disinggung oleh Plato dan Aristoteles, dan al-Fârâbî mempertegas dalam sebuah teori. Baca HZA Ahmad, al-Madinah al-Fadilah: Sebuah Komentar (Jakarta: PT. Kinta, 1968), 54.

37 al-Fârâbî, Kitâb Ârâ Abl al-Madînah al-Fâdilah, 114.

38 Lihat Imam Muslim al-Naysâbûrî, Șaĥh Mu Muslim, hạadith nomor 2586 (Beirut: Dâr alKutub al-'Ilmîyah, 2008), 1001.

39 Sirajuddin Zar, Filsafat Islam: Filosof dan Filsafatnya (Jakarta: Rajawali Pers, 2010), 84. Kapitalisme pada dasarnya ditunggangi oleh kepentingan penguasaan ekonomi. Dasar kapitalisme adalah persaingan. Ada dua perkembangan khas dalam dinamika kapitalisme. Pertama, kecenderungan untuk menyederhanakan susunan kelas sosial. Kedua, pembentukan proletariat sebagai kelas militan dan revolusioner. Dari ketidakpuasan terhadap sistem ini yang kemudian melahirkan sosialisme. Baca MagnisSuseno, Pemikiran Karl Marx, 165.

40 Imam Sukardi, Puncak Kebahagiaan (Yogyakarta: Pustaka Pelajar, 2005), 29. 
pimpinan rasio, dapat berkembang sebagaimana mestinya akan muncul manusia yang harmonis dan adil. Secara analogis dengan bagian-bagian jiwa ini, Plato menganggap bahwa negara itu laksana manusia besar, sebagai organisme yang terdiri dari tiga bagian atau tiga golongan yang masing-masing sepadan dengan bagian jiwa. Tiga golongan tersebut antara lain: pertama, golongan produktif, yang terdiri dari buruh, petani, dan pedagang, ephithymia; kedua, golongan penjaga yang terdiri dari prajurit-prajurit, thymas; dan ketiga, golongan pejabat yang memegang pucuk pimpinan dan kekuasaan. ${ }^{41}$

Ide-ide kenegaraan al-Fârâbî ini sebagaimana yang terjadi dalam sejarah para al-Khulafâ' al-Râshidûn dan sahabat-sahabat Rasulullah. Sebagaimana dijelaskan dalam sejarah, al-Khulafâ' al-Râshidûn memandang khalifah ini sebagai suatu jabatan yang dipilih dan harus diputuskan berdasarkan kerelaan kaum Muslim dan hasil musyawarah antar-mereka. Mengangkat pemimpin dengan cara pewarisan atau perebutan kekuasaan secara paksa, maka itu bagi mereka bukan merupakan "khalifah", tapi "kerajaan". ${ }^{42}$

Masyarakat juga memiliki peran dalam mengontrol kinerja pemimpin. Dalam hal ini Muhammad 'Imârah mengemukakan, peran serta dan kontrol masyarakat terhadap pemimpin itu dilakukan sesuai dengan aturan dan tata tertib yang berlaku, baik itu para proses pengangkatannya atau pada proses turunnya dari masa jabatan tersebut. Sekalipun, dalam proses turunnya dari masa jabatan dilakukan dengan pencopotan karena dinilai kurang amanah dalam memimpin, tetap hal itu harus melalui aturan dan tata tertib yang berlaku. Dalam konteks demikian, 'Imârah mengusulkan adanya sekelompok orang atau lembaga yang terdiri dari

41 P.A Van der Weij, Filsuf-filsuf Besar tentang Manusia, terj. K. Berten (Jakarta: Gramedia, 1988), 16-17.

42 Tentang karakteristik dari kepemimpinan al-Khulafâ' al-Râshidûn, serta bentukbentuk pergantian kepemimpinan pada masa mereka dapat dilihat di berbagai kitab. Di antaranya yang secara khusus membahas sistem musyawarah dapat dilihat dalam buku Pelaksanaan Musyawarah dalam Pemerintahan al-Khulafâ' al-Râshidûn oleh Zul Asyri. Meskipun ada pandangan yang berbeda, yang tidak menerima sepenuhnya tentang bentuk musyawarah sebagai bagian dari ciri pergantian pemerintahan pada masa alKhulafâ' al-R0âshidûn, karena sebagian ada yang memandang suksesi yang dilakukan oleh Abû Bakar tidak sepenuhnya melalui musyawarah. Tentu pandangan-pandangan itu semua punya dasar. Pandangan ini lebih banyak dikemukakan golongan Shî‘ah. Lihat Mambaul Ngadhimah, "Potret Keberagamaan Islam Indonesia: Studi Pemetaan pemikiran dan Gerakan Islam” dalam Jurnal Innovatio, Vol. 9, No. 1 (2010), 82. 
orang-orang yang mempunyai pengetahuan yang cukup untuk menilai hal-hal tersebut serta memberikan teguran, peringatan, dan nasehat kepada kepala negara. Tugas dari lembaga ini adalah menilai. Ia menambahkan jika yang dilakukan oleh pemimpin itu merupakan upaya sang pemimpin (dalam arti ijtihad), maka tidak wajib untuk mencopot kedudukannya. Kalau bukan karena ijtihad, seperti kecerobohan dan hawa nafsu sendiri dan sejenisnya, maka yang pertama adalah diberikan peringatan dan teguran kepadanya. Jika kepala negara itu menerimanya dan mengikuti untuk memperbaiki, kepemimpinannya dilanjutkan kembali, tetapi jika tidak, maka ia bisa dicopot dari jabatannya sebagai kepala negara. ${ }^{43}$

Manusia-menurut al-Fârâbî-bersifat sosial yang tidak mungkin hidup sendiri-sendiri. Manusia hidup bermasyarakat dan saling membantu untuk kepentingan bersama dalam mencapai tujuan hidup, yakni kebahagiaan. ${ }^{44}$ Sifat dasar inilah yang mendorong manusia hidup bermasyarakat dan bernegara. Menurutnya, masyarakat terbagi menjadi dua macam, yakni masyarakat sempurna dan masyarakat tidak sempurna. Masyarakat yang disebut pertama, yakni masyarakat kelompok besar bisa berbentuk masyarakat kota, bisa pula masyarakat yang terdiri dari beberapa bangsa yang bersatu dan bekerja sama secara internasional. Sementara itu, masyarakat yang disebut kedua, seperti masyarakat dalam satu keluarga atau masyarakat se-desa. Masyarakat yang terbaik adalah warga masyarakat yang bekerja sama, saling membantu untuk mencapai kebahagiaan. Masyarakat seperti ini ia sebut dengan masyarakat utama. ${ }^{45}$

\section{Relevansi Pemikiran al-Fârâbî dalam Pemikiran Politik Modern}

\section{Konvergensi al-Madînah Al-Fâdilah dengan Good Governance}

Pengertian pemimpin utama, menurut al-Fârâbî, menunjuk pada orang yang diikuti dan diterima. Diterima dengan alasan bahwa dia adalah orang yang memiliki kesempurnaan tujuannya. Apabila perbuatanperbuatan, keutamaan-keutamaan, dan kreativitasnya tidak seperti yang dikehendaki masyarakat, maka kepemimpinannya tidak bisa diterima. Dengan kata lain, pemimpin adalah orang yang paling utama, paling

\footnotetext{
43 Muhammad 'Imârah, Islâm wa Falsafat al-Hukm (Beirut: Dâr al-Shurûq, 1989), 495. 44 al-Fârâbî, Kitâb Ârâ' Abl al-Madinah al-Fâdilah, 118. Lihat juga al-Fârâbî, Kitâb alMillah, 53.

45 al-Fârâbî, Kitâb Ârâ Abl al-Madinah al-Fâdilah, 117. Lihat juga al-Fârâbî, Kitâb al-Siyâsah al-Madanîyah, 69.
} 
kreatif dan memiliki tujuan yang paling utama. Semua itu tidak mungkin terjadi apabila dia tidak memiliki ilmu-ilmu teoretis dan keutamaan berpikir sebagaimana yang dimiliki oleh seorang filsuf. ${ }^{46}$ Dalam pengertian ini, al-Fârâbî beranggapan bahwa antara filsuf dan pemimpin utama memiliki satu pengertian atau menunjuk pada pengertian yang sama.

Pimpinan utama, menurutal-Fârâbî, adalah pemegang otoritas utama yang tidak mungkin dipimpin atau diatur oleh pihak lain. Demikian pula pimpinan utama dalam al-Madinah al-Fâdilah tidak mungkin dipimpin oleh pihak-pihak lain di sekitar dia. Dia adalah orang yang menjadi panutan bagi pemimpin-pemimpin yang lain dalam segala hal, dan di tangan dialah segala persoalan dalam al-Madinah al-Fâdilah itu bermuara. Dia adalah orang yang paling sempurna di antara yang lain. Dia adalah 'aqlsekaligus $m a^{6} q \hat{u} l$, daya khayalnya secara natural telah mencapai puncak kesempurnaan. Daya ini adalah daya yang secara natural ada padanya setiap saat. Hal itu muncul dari akal aktif partikular baik dengan sendirinya maupun disebabkan oleh pengaruh lain. Akal potensial telah mencapai kesempurnaan dengan segala bentuk, sehingga dapat melepaskan arti-arti materinya dan menjadi akal aktual. ${ }^{47}$

Barangsiapa yang akal potensialnya telah mencapai kesempurnaan dengan segala bentuk, menjadi akal aktual, ia telah mencapai sesuatu yang tingkatannya di atas akal potensial. Ia lebih sempurna dan berpisah dengan materi, dekat dengan akal aktif, yang disebut dengan akal mustafâd. Dia berada di tengah-tengah antara akal potensial dan akal mustafâd, di saat itu tidak ada lagi pembatas antara dirinya dan akal aktif. ${ }^{48}$

Pemimpin yang sesungguhnya adalah pemimpin yang tujuan utama dari segala apa yang dilakukannya dapat memberi manfaat kepada diri dan para warganya dalam meraih kebahagiaan. Hal ini merupakan tugasnya sebagai pemimpin. Untuk itu pimpinan al-Madînah al-Fậilah harus orang yang paling sejahtera di antara yang lain karena dia akan menjadi sebab kesejahteraan para warga negara. ${ }^{49}$

Menurut al-Fârâbî, pimpinan di dalam al-Madînah al-Fâdilah punya kecenderungan untuk tidak peduli pada hal-hal yang bersifat materi.

\footnotetext{
46 al-Fârâbî, Kitâb Tạ̣sîl al-Sa'âdah, 43.

${ }^{47}$ al-Fârâbî, Kitâb Ârâ' Abl al-Madinah al-Fạdilah, 123.

48 Ibid., 123-124.

49 Abû Naṣr al-Fârâbî, Fuṣull Muntaza'ah (Beirut: Dâr al-Mashriq, 1993), 47.
} 
Artinya, dia sudah sampai pada tingkatan akal mustafâd yang mampu berkomunikasi dengan akal aktif, sedangkan yang lainnya tidak demikian. Dia fokus pada satu tujuan utama, yaitu mengabdi kepada Sebab Pertama, tunduk kepada-Nya dan mencukupkan diri hidup untuk-Nya. Pimpinan-pimpinan di bawahnya atau bahkan masyarakat umum mengikuti apa yang dilakukan pimpinan utama, sekalipun sempurna sebagaimana pimpinannya. ${ }^{50}$

Akal aktif adalah sesuatu yang menyebabkan terlepasnya arti-arti dari materinya, arti-arti itu telah mempunyai wujud dalam akal, dengan sebenarnya, bukan lagi dalam bentuk potensial, tetapi dalam bentuk aktual. Yang dapat menangkap akal aktif itu adalah daya berpikir. Daya berpikir terdiri dari dua macam, yaitu: daya berpikir teoretis dan daya berpikir praktis. Daya berpikir praktis adalah daya berpikir yang berimplikasi pada juz'iyat (partikular), sekarang dan yang akan datang, sedangkan daya pikir teoretis meliputi bentuk-bentuk materi yang belum diketahui. Daya imajinasi merupakan perantara untuk dua jenis daya pikir ini. $^{51}$

Akal aktif yang ditangkap oleh daya imajinasi itu dapat bereaksi pada diperolehnya sesuatu yang berupa bentuk-bentuk materi (al-ma'qûlât), yang dihasilkan oleh daya pikir teoretis dan kadang-kadang dapat berupa juz'iyat al-maḥsûsat (partikular indrawi) yang dihasilkan oleh daya pikir praktis. Daya imajinasi itu menangkap arti dari bentuk-bentuk indrawi yang telah tersusun sebagaimana adanya dan kadang-kadang menerima partikularnya setelah melalui proses imajinatif dan juga kadang-kadang diikuti pula dengan benda-benda indrawi. ${ }^{52}$ Apa yang diberikan oleh akal aktif kepada manusia melalui daya imajinasi itu bisa terjadi ketika ia dalam keadaan tidur, yaitu berupa mimpi dan dapat pula dalam keadaan terjaga dengan penglihatan yang benar terhadap sesuatu. ${ }^{53}$

Orang dapat berhubungan dengan akal aktif melalui dua cara. Apabila akal potensial dalam diri seseorang menjadi akal aktual, akal aktual menjadi akal mustafâd kemudian akal mustafâd dapat bersatu dan berhubunngan dengan akal aktif maka dia menjadi filsuf. Sementara itu, nabi dapat bersatu dan berhubungan dengan akal aktif melalui daya

\footnotetext{
50 al-Fârâbî, Kitâb Ârâ' Abl al-Madînah al-Fâdilah, 122.

51 Ibid., 111.

${ }^{52}$ Ibid., 112. Lihat juga al-Fârâbî, Kitâb al-Siyâsah al-Madanîyah, 34-35.

53 Ibid., 112.
} 
khayalnya yang sangat kuat. Dia adalah manusia yang paling tinggi tingkatannya dan dapat memperoleh kebahagiaan yang paling tinggi. Nabi memiliki jiwa yang sempurna dan selalu bersatu dengan akal aktif. Segala apa yang dilakukannya selalu mengarah kepada kebahagiaan. Inilah sebenarnya yang pertama-tama menjadi persyaratan bagi seorang pemimpin. ${ }^{54}$

Karena sedemikian mulia dan tingginya derajat pimpinan utama dalam al-Madinah al-Fâdilah, sehingga memang tidak semua orang bisa menempati posisi tersebut. Ia merupakan fitrah dan karakteristik bawaan, atau bisa juga melalui usaha keras sekalipun berat untuk mencapainya. Suatu kepemimpinan akan sukses apabila berada di tangan orang yang memiliki fitrah dan karakteristik bawaan memimpin. Dalam kepemimpinan itu tidak cukup hanya berbekal keterampilan saja, karena sebagian besar dari keterampilan-keterampilan itu adalah keterampilan yang dipelajari secara khusus dan diarahkan untuk tujuan mengabdi dalam sebuah negara. Fitrah dan karakteristik yang melekat pada pimpinan utama adalah fitrah dan katakteristik pengabdian. ${ }^{55}$

Adapun persyaratan yang lain adalah dia harus pandai menyampaikan dengan baik apa yang diketahuinya melalui daya khayal, mampu menasihati orang lain dan menunjukkannya jalan menuju kebahagiaan, bekerja agar dapat memperoleh kebahagiaan dan memiliki kemampuan untuk memberi contoh tentang cara-cara melakukan pekerjaan dengan baik. ${ }^{56}$ Dalam menjalankan pemerintahannya, menurut al-Fârâbî, juga harus membuat kesepakatan bersama. Hal ini dilakukan, karena dalam kehidupan bersama ibaratanya satu tubuh dan jiwa. Jadi, dalam hal apapun harus didasarkan pada kesepakatan bersama. ${ }^{57}$

Apa yang dipaparkan oleh al-Fârâbî tentang pemimpin dalam melaksanakan pemerintahannya sejalan dengan konsepsi good governance. Ada dua konsepsi dalam good governance: pertama, nilai yang menjunjung tinggi kehendak rakyat, dan nilai-nilai yang dapat meningkatkan kemampuan rakyat dalam pencapaian tujuan kemandirian, pembangunan berkelanjutan dan keadilan sosial. Kedua, aspek fungsional dari

\footnotetext{
${ }^{54}$ Ibid., 124-125. Lihat juga al-Fârâbî, Kitâb al-Siyâsah al-Madanîyah, 79.

55 Ibid., 120-121.

56 Ibid., 126.

${ }^{57}$ al-Fârâbî, Kitâb al-Siyâsah al-Madanîyah, 80.
} 
pemerintah yang efektif dan efisien dalam pelaksanaan tugasnya untuk mencapai tujuan tersebut. ${ }^{58}$

Dengan demikian, peran pemerintah pada akhirnya perlu dibekali dengan kemampuan diri dan kompetensi untuk menjembatani konflik di antara berbagai kelompok kepentingan dan berbagai hambatan lainnya dalam kerangka sosial politik. Pola interaksi dan kolaborasi antara pemerintah dan swasta maupun masyarakat, yang sering disebut dengan istilah kemitraan, telah banyak dilakukan di berbagai sektor. Pola pengelolaan program pada umumnya diarahkan untuk menemukan bentuk yang tepat dalam rangka memecahkan berbagai permasalahan dalam masyarakat, atau mungkin juga dalam rangka menemukan format baru penyelenggaraan pemerintahan, pembangunan, dan pelayanan publik. ${ }^{59}$

\section{Relevansi al-Siyâsah al-Madanîyah dalam Pemikiran Demokrasi dan Civil Society}

\section{a. Demokrasi}

Dalam al-Madînah al-Jâhiliyahyang merupakan bagian dari negara yang tidak ideal menurut al-Fârâbî, memuat pembahasan tentang kebebasan (al-ḥurrîyah). Masyarakat bebas ini diistilahkan oleh al-Fârâbi sebagai alMadinah al-Jamâîyah, yaitu suatu negara yang tujuan inti para warganya adalah memperoleh kebebasan yang tanpa batas untuk melampiaskan hawa nafsu. Dalam negara itu tak seorangpun berhak melarang apa yang menjadi keinginan dan apa yang dilakukan oleh warga negara.

$$
\begin{aligned}
& \text { أمّا المدينة الجماعيّة فهي المدينة التي كلّ واحد من أهلها مطلق مخليّ لنفسه يعمل ما يشاء. وأهلها }
\end{aligned}
$$

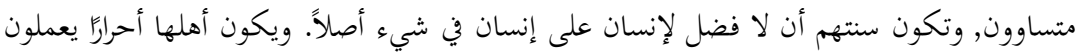

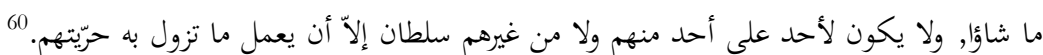

Dalam pembahasan tersebut terlihat bahwa yang ditolak oleh alFârâbî adalah kebebasan yang tanpa batas, sebab dalam kesempatan lain al-Fârâbî menganalogikan kehidupan bernegara menggunakan teori

58 Sedarmayanti, Good Governance dan Good Corporate Governance (Bandung: Mandar Maju, 2007), 245. Lihat juga Syulhennisari Siregar, et.al, "Fenomena Globalisasi dan Tantangan terhadap Good Governance dalam Mewujudkan Civil Society", dalam Jurnal Ilmu-ilmu Sosial, Vol. 10, No. 1 (Februari 2009), 94.

59 Nasruddin Anshoriy, Dekonstruksi Kekuasaan: Konsolidasi Semangat Kebangsaan (Yogyakarta: LKiS, 2008), 33-34. Baca juga Ambar Teguh Sulistiyani, Memahami Good Governance Perspektif Sumber Daya Manusia (Banten: Gaya Media, 2004), 34.

${ }^{60}$ al-Fârâbî, Kitâb al-Siyyâsah al-Madanîyah, 99. 
organis, di mana negara tak ubahnya bagaikan susunan tubuh manusia yang sehat dan sempurna. Masing-masing anggotanya bekerja sama untuk menyempurnakan dan memelihara segala kebutuhan hidup bersama. Setiap anggota tubuh memiliki fungsi dan kemampuan berbedabeda yang masing-masing bertugas sesuai dengan kemampuan dan kesanggupannya. Di atas semua itu ada satu anggota yang berfungsi sebagai kepala yang mengendalikan segala gerak dari keseluruhan bagian tubuh yang lain yaitu al-qalb (hati). Demikian pula dengan negara, masing-masing rakyatnya mempunyai tugas dan kecakapan yang berbeda, dipimpin oleh seorang kepala negara, sedangkan yang lainnya membantu dalam berbagai kedudukan. ${ }^{61}$ Artinya, kalau kebebasan masyarakat masih dalam kontrol dan ada batasan-batasan tertentu, maka sepertinya alFârâbî memandangnya sebagai hal yang bagus.

Memang terdapat perbedaan antara kebebasan yang diakui oleh demokrasi liberal dan Islam, menurut Masykuri Abdillah. Dalam demokrasi liberal, kebebasan menekankan kemampuan berbuat tanpa batas, sedangkan dalam Islam kebebasan menekankan kemampuan untuk bereksis. Perbedaan ini terutama disebabkan oleh perbedaan konsep tentang hukum yang diakui sebagai satu-satunya pembatasan kebebasan. Hukum Islam meliputi kehidupan personal dan inter-personal, sementara hukum dalam sistem liberal hanya meliputi kehiduapan inter-personal. Dalam Islam seseorang tidak bisa melakukan apa saja yang dia inginkan, bahkan dalam wilayah pribadi sekali pun, yang secara tidak langsung berkaitan dengan kehidupan masyarakat. Pada sistem liberal, seseorang bisa melakukan apa saja dalam wilayah pribadi tanpa ada batas. Selanjutnya, hukum dalam demokrasi liberal dengan mudah dapat diubah dengan hukum baru yang lebih akomodatif terhadap kehendak rakyat untuk mendapatkan kebebasan yang lebih besar, sementara hukum Islam tidak bisa diubah begitu saja. Hanya hukum Islam yang dihasilkan dari ijtihad (pernyataan seseorang atau penafsiran atas doktrin-doktrin Islam) yang dapat diubah, sedangkan hukum yang ditentukan dalam al-Qur'ân dan al-Sunnah secara qat'î tidak dapat diubah. Konsekuensinya, batasbatas kebebasan dalam Islam tampak lebih ketat ketimbang dalam sistem demokrasi liberal. ${ }^{62}$

${ }^{61}$ al-Fârâbî, Kitâb Ârâ' Abl al-Madinah al-Fâdilah, 118.

62 Abdillah, Demokrasi di Persimpangan Makna, 145-146. 
Oleh karena itu, tidak berlebihan kiranya kalau pemikiran al-Fârâbî ini dijadikan landasan oleh pakar politik setelahnya untuk mengatakan bahwa hal itu adalah benih munculnya demokrasi, sekalipun al-Fârâbî sendiri tidak pernah menyebut kata demokrasi dalam karya-karyanya. Misalnya, Franz Rosenthal dalam bukunya The Muslim Concept of Freedom mengatakan bahwa ide demokrasi itu telah dilontarkan oleh al-Fârâbî abad ke-9 Masehi yang lalu.

"The idea of democracy as the freedom state was adapted by al-Farabi to his own political thinking in one of his political writings, the Kitab alSiyasah al-Madaniyah, presumably a genuine work of the famous philosopher". ${ }^{63}$

Sekalipun yang penting untuk digarisbawahi, al-Fârâbî dalam pemikirannya tidak bisa dilepaskan dari pengaruh pemahaman keagamaannya, Islam. Artinya, dalam kehidupan bernegara, al-Fârâbî tetap memimpikan sebuah tatanan yang diwarnai oleh nilai-nilai Islam.

\section{b. Civil Society}

Menurut al-Fârâbî warga negara ideal adalah warga negara yang berfungsi bagaikan tubuh, di mana anggota tubuhnya bekerja sama sesuai dengan tugas masing-masing. Mereka terkoordinir dengan rapi demi kesempurnaan hidupnya. Pekerjaan yang terpenting dalam masyarakaat adalah pekerjaan pemimpin, yang dalam tubuh manusia serupa dengan alqalb. Pemimpin merupakan sumber dari segala peraturan dan keharmonisan dalam masyarakat. Ia mesti sehat jasmani dan rohani, serta memiliki kearifan. ${ }^{64}$ Hanya saja dalam membuat keputusan, pemimpin harus tetap memberikan kesempatan pada masyarakat atau elemen lain untuk terlibat juga. Jadi, dalam membuat keputusan harus didasarkan pada kesepakatan bersama. ${ }^{65}$ Dengan kata lain, pemimpin itu tidak hanya bekerja berdasarkan keinginannya sendiri, tapi juga untuk orang lain. ${ }^{66}$

Dari penjelasan tentang civil society tersebut terlihat jelas bahwa apa yang diinginkan dan diidealkan oleh al-Fârâbî dengan istilah al-Madînah al-Fâdilab itu adalah civil society itu sendiri. Artinya, ada kesamaan di antara keduanya. Hal ini bisa dilihat dalam persyaratan yang diajukan oleh alFârâbî tentang terciptanya masyarakat ideal itu, yaitu kerjasama antar

\footnotetext{
${ }^{63}$ Franz Rosenthal, the Muslim Concept of Freedom (Leiden: E.J. Brill, 1960), 100.

${ }^{64}$ al-Fârâbî, Kitâb Ârâ' Abl al-Madinah al-Fậilah, 120.

65 al-Fârâbî, Kitâb al-Siyâsah al-Madanîyah, 80.

66 al-Fârâbî, Kitâb Arâ' Abl al-Madînah al-Fâdilah, 92.
} 
berbagai elemen masyarakat dalam membangun negara. ${ }^{67}$ Kerjasama berbagai elemen dalam masyarakat itu bisa dilihat misalnya dalam masyarakat yang disebut oleh al-Fârâbî dengan al-Nawâbit, di mana di dalamnya banyak komunitas yang dengan bebas melakukan segala untuk berkontribusi pada kehidupan negara. Di antara komunitas itu ada yang disebut dengan al-Mutaqannisûn (orang yang berburu). Muharrifûn (orang yang menyelewengkan), al-Mâriqah (orang yang keluar dari ketentuan), alMustarshidûn (orang yang mencari keterangan), al-Muzayyafûn (orang yang memalsukan). ${ }^{68}$

Jadi, tokoh-tokoh Muslim seperti al-Fârâbî, al-Mawardi dan Ibn Taimiyah, berpandangan bahwa warga negara atau masyarakat yang baik adalah masyarakat yang terikat oleh hukum, atau masyarakat yang tingkat penegakan hukumnya tinggi dan menjunjung tinggi etika, khususnya hukum dan etika Islam. Pada masa Rasulullah di Madinah civil society sebenarnya telah dipraktikkan, sekalipun tidak sama persis dengan definisi civil society sekarang. ${ }^{69}$

Maka dari itu, tantangan umat Islam Indonesia ke depan adalah membentuk masyarakat dengan mental madani dan membentuk infrastruktur yang kuat sebagai penopang terbentuknya civil society. Dari sini dapat dipahami ada hubungan erat antara sosial kapital dan civil society. Sosial kapital terdiri dari sekumpulan sokongan kultur yang dapat menfasilitasi performa sosial, jadi performa sosial yang efektif dibutuhkan tidak hanya berupa materi, tetapi institusi-institusi sosialyang mengoordinasikan sumber daya sosial yang ada, terbentuknya pemerintahan yang demokratis tidak hanya tergantung pada pemilihan umum atau konstitusi, tetapi juga sokongan-sokongan yang terdapat

67 Ibid., 88.

68 al-Fârâbî, Kitâb al-Siyâsah al-Madanîyah, 104-105.

${ }^{69}$ Pada masa Nabi Muhammad, civil society bisa dilihat dari peristiwa yang terdapat dalam Perang Uhud. Untuk menghalau serangan kedua Quraisy yang berkekuatan 3.700 orang, dalam perang ini disepakati bertahan di dalam kota yang disetujui 'Abd Allah b. Ubay (pimpinan kaum munafik yang tidak menyukai kehadiran nabi). Akan tetapi, kemudian muncul pendapat yang mengusulkan untuk keluar dari kota Madinah. Mengingat pendapat ini menjadi mayoritas, dengan kesepakatan Bukit Uhud sebagai tempat untuk menghadapi kekuatan ofensif Mekkah, nabi pun mengikutinya. Salah satu akibatnya, Ibn Ubay kecewa yang menyebabkan ia di tengah jalan dengan 300 pasukan yang mendukungnya membelot, mengundurkan diri dari peperangan. Lihat Sukron Kamil, Pemikiran Politik Islam Tematik (Jakarta: Kencana, 2013), 151. 
dalam masyarakat secara keseluruhan. ${ }^{70}$ Sokongan kultur sosial ini termasuk di dalamnya, kultur politik atau political culture yang menjamin kebebasan seluruh warga negara, toleransi dan menghormati hukum yang ditetapkan. Dari semua sumber daya sosial yang tersebut inilah akan terbentuk organisasi sosial yang lebih dikenal dengan istilah civil society, atau meminjam istilah Cak Nur, masyarakat madani.

\section{Koeksistensi Masyarakat dan Negara dalam Dinamika Politik Indonesia}

Meletakkan pemikiran politik al-Fârâbî dalam konteks Indonesia, tidak sepenuhnya kompatibel. Pada sisi pembangunan demokrasi, good governance dan civil society ada kesesuaiannya, tetapi pada sisi kemajemukan, luasnya masyarakat dan territorial Indonesia mungkin kurang begitu serasi. Hal ini karena al-Fârâbî mengidealkan sebuah negara kecil (almadinab) yang terinspirasi dari pemikiran Plato, yaitu polis. ${ }^{72}$

Koeksistensi negara dan masyarakat dalam pembagian kekuasaan secara mendasar dibagi dua macam, antara lain: pertama, suprastruktur, yaitu kekuasaan yang ada di dalam negara; kedua, infrastruktur, yaitu kekuasaan yang ditujukan kepada negara. ${ }^{73}$ Infrastruktur suatu negara pada umumnya terdiri dari partai politik, golongan kepentingan, golongan penekan, media komunikasi politik, dan tokoh politik. Di sini civil society menjadi bagian tak terpisahkan dalam infrastruktur negara. Teori pembagian kekuasaan, sebagaimana dilontarkan oleh John Locke atau Montesquieu (1689-1755 M), masuk dalam kategori suprastruktur.

Secara historis, kesadaran masyarakat untuk berperan serta dalam kehidupan bernegara cukup tinggi di Indonesia, baik sebelum kemerdekaan ataupun pasca-kemerdekaan. Hanya saja, beberapa tahun saat kekuasaan Orde Baru partisipasi masyarakat ditekan sehingga masyarakat tidak bisa berpartisipasi secara maksimal, bahkan hilang sama

70 Robert W. Hefner, Civil Islam: Muslim and Democratization in Indonesia (Pakistan: Priceton University Press, 2000), 23.

71 Sufyanto, Masyarakat Tamaddun: Kritik. Hermeneutis Masyarakat Madani Nurcholish Madjid (Yogyakarta: Pustaka Pelajar, 2001), 100. Baca juga Mohammad Monib dan Islah Bahrawi, Islam dan Hak Asasi Manusia dalam Pandangan Nurcholish Madjid (Jakarta: Gramedia Pustaka Utama, 2011), 212.

72 al-Fârâbî, Kitâb al-Siyâsah al-Madanîyah, 13.

73 Beddy Iriawan Maksudi, Sistem Politik Indonesia: Pemahaman Secara Teoritik dan Empirik (Jakarta: Raja Grafindo Persada, 2013), 264. Lihat juga Ramlan Surbakti, Memahami Ilmu Politik (Jakarta: Grasindo, 2005), 241. 
sekali. Pascareformasi, peluang partisipasi tersebut mulai terbuka lagi. Dengan kesadaran akan kondisi tersebut, mereka kian sulit untuk dibohongi. Banyaknya penyimpangan, masyarakat menjadi bertambah keras tuntutannya. Di pihak lain, ada sebagian dari anggota masyarakat kita yang sudah meningkat kemampuan ekonomisnya. Munculnya sejumlah konglomerat yang makin banyak jumlahnya, perlu diberi kepercayaan untuk mengambil sebagian peran negara di dalam pembangunan. ${ }^{74}$ Sekalipun kadang kehadiran mereka juga memunculkan perilaku tak terpuji, ${ }^{75}$ seperti kolusi dan nepotisme, dan tindakantindakan yang merugikan perekonomian bangsa.

Untuk mendorong terciptanya suatu perkembangan politik yang baik, teladan, etika politik, dan keterbukaan serta kepastian hukum harus segera dimasyarakatkan. Meski harus dikatakan bahwa kesadaran masyarakat kita akan persoalan politik relatif jauh dibandingkan dengan masyarakat di negara lain, termasuk negara tetangga kita, tidak berarti bahwa ia akan berdampak negatif terhadap persatuan bangsa. Kita rasanya tidak memiliki pemisahan yang jelas antara politik dengan aspek lainnya. Bahkan dalam banyak hal, politik masih tetap mendominasi berbagai segi kehidupan masyarakat. Nampaknya, kurang menarik bila segalanya dapat berjalan dengan lancar tanpa bumbu politik di dalamnya. Oleh karena itu pula, barangkali kita tidak pernah percaya bila politik dapat dipisahkan dari aspek-aspek lainnya, sekalipun tidak sedikit bukti menunjukkan bahwa melalui politik pula seseorang dapat mencapai karir atau kehidupan yang lebih baik. ${ }^{76}$

${ }^{74}$ Indria Samego, "Negara, Masyarakat dan Pemilu: Catatan Pengantar" dalam Syarofin Arba (ed.), Demitologisasi Politik Indonesia (Jakarta: Pustaka Cidesindo, 1998), xvii-xviii.

75 Jakob Oetama, "Kontrol Masyarakat dan Pertumbuhan Masyarakat Bisnis" dalam Elza Peldi Taher, Demokratisasi Politik, Budaya, dan Ekonomi (Jakarta: Yayasan Paramadina, 1994), 52.

76 Dalam ilmu politik partisipasi diartikan sebagai upaya warga masyarakat, baik secara individual atau pun kelompok, untuk ikut serta mempengaruhi pembentukan kebijakan publik dalam sebuah negara. Partisipasi ini dilakukan dengan berbagai macam cara, antara lain secara langsung ataupun secara tidak langsung. Secara langsung dilakukan dengan melalui kontak-kontak dengan para pejabat negara yang ikut menentukan dalam pembuatan kebijakan politik, sedangkan secara tidak langsung dapat dilakukan melalui media massa yang ada, misalnya dengan menulis pikiran pembaca pada sebuah koran atau majalah tentang hal-hal yang menjadi agenda publik. Partisipasi dapat dilakukan secara konvensional maupun secara tidak konvensional. Partisipasi secara konvensional dilakukan melalui cara-cara yang umum dikenal dalam sebuah sistem politik, misalnya 
Pemikiran demikian akhirnya menyeret banyak kalangan untuk berkiprah di dalam partai politik. Padahal di Indonesia, selain ada partai politik, kehadiran organisasi massa, baik yang bersifat konvensional ataupun yang non-konvensional, diakui sebagai sesuatu yang dapat mewarnai kehidupan politik, sekalipun sistem kepartaian yang dianut sekarang cukup hegemonik. ${ }^{77}$ Organisasi Islam seperti Nahdhatul Ulama dan Muhammadiyah serta sejumlah organisasi keagamaan lainnya memainkan peran sangat besar apabila ada hal-hal yang mengharuskan mereka terlibat di dalamnya. ${ }^{78}$

\section{Catatan Akhir}

Menurut al-Fârâbî, masyarakat merupakan elemen penting dalam rangka terbentuknya negara. Dalam kehidupan bernegara, masyarakat justru harus ikut serta memberikan kontribusi sesuai dengan kapabilitas masing-masing. Peran masyarakat itu diibaratkan oleh al-Fârâbî dengan anggota tubuh manusia, di mana masing-masing elemen bekerja sesuai dengan kapasitasnya tanpa overlapping. Namun, dari semua elemen tersebut yang paling sentral adalah al-qalb yang dalam bahasa politiknya al-Fârâbî dianalogikan dengan pemimpin. Pemimpin memiliki peran penting dalam mengatur kehidupan bersama, tetapi tetap membutuhkan bantuan dan kerjasama yang baik dari orang lain. Oleh karena itu, alFârâbî menginginkan adanya kebebasan (al-ḅurrîyah) seluruh masyarakat agar bisa melakukan aktivitasnya sesuai dengan kapasitas masing-masing. Tugas pemimpin hanya memberikan arahan agar sesuai dengan tuntunan agama dan tidak melenceng dari tujuan terbentuknya negara, yaitu tercapainya kebahagiaan (al-sa'âdab) dunia dan akhirat.

Pemikiran al-Fârâbî yang tertuang di dalam karya-karyanya, terutama dalam Kitâb al-Siyâsah al-Madanîyah dan Kitâb Arâ' Abl al-Madînah alFâdilah, memberikan kontribusi besar terhadap perkembangan demokrasi selanjutnya. Dua karya itu membahas tentang kehidupan bernegara mulai

dengan menjadi anggota sebuah partai politik dan organisasi kepentingan, sementara secara tidak konvensional dapat dilakukan dengan cara unjuk rasa, bahkan ada yang menempuh cara-cara kekerasan. Afan Gaffar, "Merangsang Partisipasi Politik Rakyat" dalam Syarofin Arba (ed.), Demitologisasi Politik Indonesia (Jakarta: Pustaka Cidesindo, 1998), 240. Lihat juga Samego, "Negara, Masyarakat dan Pemilu”, xviii.

77 Gaffar, "Merangsang Partisipasi Politik", 245.

78 Ahmad Hasyim Muzadi, "Nahdhatul Ulama Mengabdi untuk Bangsa", dalam Jurnal Tashwirul Afkar, edisi no. 27, tahun 2009, Lakpesdam NU, 35-36. 
dari persyaratan pemimpin, kerjasama pemimpin dengan masyarakat, peran masyarakat dalam kehidupan bernegara, sampai kehidupan bersama antar masyarakat. Pemikiran al-Fârâbî tersebut muncul Abad Pertengahan di saat dunia, terutama di Barat, mengalami kemunduran akibat dominasi gereja yang sangat tinggi. Sekalipun, yang perlu dipahami bahwa konsep demokrasi yang ada sekarang sudah mengalami perkembangan seiring berjalannya waktu dan perkembangan peradaban manusia. Dengan kata lain, kalau dulu al-Fârâbî menawarkan pemikiran politik yang dianggap sebagai fondasi demokrasi abad modern, tetapi pemikiran al-Fârâbî masih berada dalam pengaruh religiositasnya sebagai penganut agama Islam. Hal itu terlihat dari pemikirannya tentang kebebasan, misalnya. Ia menganggap kebebasan (al-ḥurriyah) sebagai bagian dari al-Madînah al-Jâhilîyah, bukan al-Madînah al-Fâdilah yang diidealkan olehnya, tetapi hal ini kemudian ditafsirkan ulang oleh cendekiawan selanjutnya, bahwa yang dimaksud dengan kebebasan menurut al-Fârâbî tersebut adalah kebebasan yang tanpa batas. Selama masih dalam kontrol pemimpin, kebebasan tersebut justru menjadi salah satu modal terciptanya al-Madinah al-Fâdilah.

\section{Daftar Rujukan}

Abdillah, Masykuri. Demokrasi di Persimpangan Makna. Yogyakarta: Tiara Wacana, 1999.

Ahmad, HZA. al-Madinah al-Fadilah: Sebuah Komentar. Jakarta: PT. Kinta, 1968.

Anshoriy, Nasruddin. Dekonstruksi Kekuasaan: Konsolidasi Semangat Kebangsaan. Yogyakarta: LKiS, 2008.

Apter, David E. Pengantar Analisa Politik, terj. Setiawan Abadi. Jakarta: LP3ES, 1987.

Basroh, Abu Daud. Ilmu Negara. Jakarta: Bumi Aksara, 2010.

Budiyono, Kabul. Teori dan Filsafat Ilmu Politik. Bandung: Penerbit Alfabeta, 2012.

Claeys, Gregory. Thomas Paine, Social and Political Thought. Wellington: Unwin Himan, t.th.

Edwards, Paul. The Encyclopedia of Philosophy. New York: Macmillan dan Free Press, 1972.

Fârâbî (al), Abû Nașr. Fușûl Muntą̧a 'ah. Beirut: Dâr al-Mashriq, 1993.

----. Kitâb al-Millah wa Nusûș Ukhrâ. Beirut: Dâr al-Mashriq, 1986.

----. Kitâb al-Siyâsah al-Madanîyah. Beirut: Dâr al-Mashriq, 1993. 
----. Kitâb Ârâ' Abl al-Madînah al-Fâdilah. Beirut: Dâr al-Mashriq, 1996. Foner, Philip S. (ed.). The Complete Writings of Thomas Paine: With a Biographical Essay, and Notes, and Introductions Presenting the Historical Background of Paine's Writings. New York: The Citadel Press, 1945.

Gaffar, Afan. "Merangsang Partisipasi Politik Rakyat" dalam Syarofin Arba (ed.), Demitologisasi Politik Indonesia. Jakarta: Pustaka Cidesindo, 1998.

Giddens, Antony. Capitalism and Modern Social Theory: an Analysis of Writings of Marx, Durkheim, and Max Weber. London: Cambridge University Press, 1971.

Hakim, Atang Abdul dkk. Filsafat Umum: dari Mitologi sampai Teofilosofi. Bandung: CV. Pustaka Setia, 2008.

Hann, Chris. "Political Society and Civil Anthropology", dalam Chris Hann dan Elizabeth Dunn, Civil Society: Challenging Western Models. New York: Routledge, 1996.

Hefner, Robert W. Civil Islam: Muslim and Democratization in Indonesia. Pakistan: Priceton University Press, 2000.

'Imârah, Muhammad. Islâm wa Falsafat al-Ḥukm. Beirut: Dâr al-Shurûq, 1989.

Jindan, Khalid Ibrahim. Teori Politik Islam: Telaah Kritis Ibnu Taimiyah tentang Pemerintahan Islam, terj. Masrohin. Surabaya: Risalah Gusti, 1995.

Kamil, Sukron. Pemikiran Politik Islam Tematik. Jakarta: Kencana, 2013. Khaldûn, Ibn. Muqaddimah. Beirut: Dâr al-Fikr, t.th.

Khan, Qamaruddin. Kekuasaan, Pengkhianatan dan Otoritaas Agama: Telaah Kritis Teori al-Mawardi tentang Negara. Yogyakarta:Tiara Wacana, 2000. Khumaini, Imam. al-Hukêmah al-Islâmîyah. Iran: al-Ḥarakah al-Islâmiyah, $1389 \mathrm{H}$.

Magnis-Suseno, Franz. Pemikiran Karl Marx: Dari Sosialisme Utopis ke Perselisihan Revisionisme. Jakarta: Gramedia Pustaka Utama, 2005.

----- Etika Politik. Jakarta: Gramedia, 1994.

Maksudi, Beddy Iriawan. Sistem Politik Indonesia: Pemahaman Secara Teoritik dan Empirik. Jakarta: Raja Grafindo Persada, 2013.

Mâwardî (al), Abû al-Ḥasan. al-Aḥkâm al-Sultânîyah. Beirut: Dâr al-Kitâb al-Alamiyah, t.th.

Mawdûdî (al), Abû A'la. The Political Theory of Islam. Pathankot: Makta-e Jama'at Islami, t.th. 
Monib, Mohammad dan Bahrawi, Islah. Islam dan Hak Asasi Manusia dalam Pandangan Nurcholish Madjid. Jakarta: Gramedia Pustaka Utama, 2011.

Mufid, Moh. Politik dalam Perspektif Islam. Jakarta: UIN Jakarta Press, 2004.

Musa, Ali Masykur. Membumikan Islam Nusantara. Jakarta: Serambi, 2014. Muzadi, Ahmad Hasyim. "Nahdhatul Ulama Mengabdi untuk Bangsa", dalam Jurnal Tashwirul Afkar, edisi no. 27, tahun 2009, Lakpesdam NU.

Nadir, al-Bier Nashri. "Nubdhah 'an Târikh Hayât al-Fârâbî", dalam alFârâbî, Kitâb al-Jam' bayn Ra'yai al-Hâkkîmayn. Beirut: Dâr al-Mashriq, 1968.

Naysâbûrî (al), Imam Muslim. Șahîh Muslim, ḥadîth nomor 2586. Beirut: Dâr al-Kutub al-'Ilmîyah, 2008.

Ngadhimah, Mambaul. "Potret Keberagamaan Islam Indonesia: Studi Pemetaan Pemikiran dan Gerakan Islam" dalam Jurnal Innovatio, Vol. 9, No. 1, 2010.

Oetama, Jakob. "Kontrol Masyarakat dan Pertumbuhan Masyarakat Bisnis" dalam Elza Peldi Taher, Demokratisasi Politik, Budaya, dan Ekonomi. Jakarta: Yayasan Paramadina, 1994.

Piscatory, James P. Islam in a World Nation-State. New York: Cambridge University Press, 1986.

Pramana, Pudja. Ilmu Negara. Yogyakarta: Graha Ilmu, 2009.

Rahardjo, Dawam. Masyarakat Madani: Agama, Kelas Menengah, dan Perubahan Sosial. Jakarta: LP3ES, 1999.

Rahman, Fazlur. "Implementation of the Concept of State in the Pakistani Milieu", Islamic Studies, No. 6, September 1967.

Rais, Amien. Indonesian Civil Society 2006. Jakarta: YAPPIKA, 2006.

Rosenthal, Franz. the Muslim Concept of Freedom. Leiden: E.J. Brill, 1960. Rousseau, Jean-Jacques. Kontrak Sosial, terj. Sumardjo. Jakarta: Erlangga, 1986.

Salim, Arskal. "Between ICMI dan NU: The Contested Representation of Muslim Civil Society in Indonesia, 1990-2001", al-Jami'ah: Journal of Islamic Studies, Vol. 49, No. 2, 2011.

Samego, Indria. "Negara, Masyarakat dan Pemilu: Catatan Pengantar" dalam Syarofin Arba (ed.), Demitologisasi Politik Indonesia. Jakarta: Pustaka Cidesindo, 1998. 
Sedarmayanti. Good Governance dan Good Corporate Governance. Bandung: Mandar Maju, 2007.

Siregar, Syulhennisari. et.al. "Fenomena Globalisasi dan Tantangan terhadap Good Governance dalam Mewujudkan Civil Society", dalam Jurnal Ilmu-ilmu Sosial, Vol. 10, No. 1, Februari 2009.

Sufyanto. Masyarakat Tamaddun: Kritik Hermeneutis Masyarakat Madani Nurcholish Madjid. Yogyakarta: Pustaka Pelajar, 2001.

Sukardi, Imam. Puncak Kebahagiaan. Yogyakarta: Pustaka Pelajar, 2005.

Sulistiyani, Ambar Teguh. Memahami Good Governance Perspektif Sumber Daya Manusia. Banten: Gaya Media, 2004.

Surbakti, Ramlan. Memahami Ilmu Politik. Jakarta: Grasindo, 2005.

Syadzali, Munawir. Islam dan Tata Negara. Jakarta: UI Press, 1990.

Weij, P.A Van der. Filsuf-filsuf Besar tentang Manusia, terj. K. Berten. Jakarta: Gramedia, 1988.

Zar, Sirajuddin. Filsafat Islam: Filosof dan Filsafatnya. Jakarta: Rajawali Pers, 2010. 